\title{
SIMULASI ALIRAN FLUIDA PADA POMPA HIDRAM DENGAN VARIASI PANJANG PIPA PEMASUKAN DAN TINGGI TABUNG UDARA MENGGUNAKAN PERANGKAT LUNAK CFD
}

\author{
Jefri H. Manik ${ }^{1}$, A. Halim Nasution ${ }^{2}$, Syahril Gultom ${ }^{3}$, Zulkifli Lubis ${ }^{4}$, Pramio G. Sembiring ${ }^{5}$ \\ 1,2,3,4,5 Departemen Teknik Mesin Fakultas Teknik Universitas Sumatera Utara Medan Indonesia \\ Email: jefrimanik@gmail.co.id
}

\begin{abstract}
ABSTRAK
Penelitian ini bertujuan untuk mensimulasikan aliran fluida pada pompa hidram dengan menggunakan perangkat lunak CFD, simulasi yang digunakan adalah untuk aliran stedi, inkompresibel, turbulen, dan tiga dimensi. Fluida air (water liquid) berakselerasi melalui pipa masuk dan masuk ke badan pompa, badan pompa mengalami kompresi dan akhirnya menekan air ke tabung udara dan kemudian menyalurkan air ke pipa keluaran. Simulasi diatur dengan mengkondisikan pada saat katup limbah tertutup dan pada saat katup penghantar tertutup. Simulasi terdiri dari sembilan rangkaian yaitu tiga panjang pipa pemasukan, tiga tabung udara $40 \mathrm{~cm}$, tiga tabung udara $60 \mathrm{~cm}$. Hasil simulasi didapatkan dengan membandingkan hasil simulasi dengan hasil pengujian. Diperoleh penyimpangan terendah antara hasil simulasi dan hasil pengujian adalah $0,05 \%$ dan penyimpangan tertinggi antara hasil simulasi dan hasil pengujian adalah $16,58 \%$.

Kata kunci : Pompa Hidram, Simulasi, CFD
\end{abstract}

\section{ABSTRACT}

This research aims to simulate a fluid flow for hydram pump using CFD software, The simulation is performed by steady flow, incompressible, turbulent and three-dimensional. Water fluid (water liquid) accelerates through the inlet pipe and entry into the pump body, pump body have a compression and then press the water into the air vessel and then draining the water into the outlet pipe. This simulate is set by conditioning when waste valve is closed and when delivery valve is closed. Simulation consist of nine series namely three the length of inlet pipe, three different height of air vessel $40 \mathrm{~cm}$, three different height of air vessel $60 \mathrm{~cm}$. Simulation result obtained by comparing simulation result and experiment result. Obtained the lowest deviation between simulation result and experiment result is $0,05 \%$ and the highest deviation between simulation result and experiment result is 16,58\%.

Keyword: Hydram Ram Pump, Simulate, CFD

\section{PENDAHULUAN}

Kenyataan telah menunjukkan bahwa ada banyak daerah dipedesaan yang mengalami kesulitan penyediaan air, baik untuk kebutuhan rumah tangga maupun untuk kegiatan pertanian. Untuk menanggulangi masalah-masalah penyediaan air baik untuk kehidupan maupun untuk kegiatan pertanian, peternakan dan perikanan khususnya didaerah pedesaan, maka penggunaan pompa Hidraulik Ram Automatik sangat menguntungkan dalam kehidupan masyarakat di pedesaan. Pompa hidraulik ram bekerja tanpa menggunakan bahan bakar atau tambahan energi dari luar. Pompa ini memanfaatkan tenaga aliran air yang jatuh dari tempat suatu sumber yang tinggi dan sebagian dari air itu dipompakan dengan pompa hidram ke tempat yang lebih tinggi. Pompa hidraulik ram ini sangat tepat untuk daerah-daerah yang penduduknya mempunyai keterampilan teknis yang terbatas, karena pemeliharaan yang dibutuhkan sederhana.

Adapun tujuan penelitian ini adalah mensimulasikan aliran fluida dalam pompa hidram, mensimulasikan distribusi kecepatan dan tekanan dan menghitung besar penyimpangan. Batasan masalah dalam penelitian ini seperti fluida yang digunakan 
adalah air, dimensi pompa digambar dengan perangkat lunak CAD, Variabel yang dibandingkan adalah kecepatan pada katup limbah $\left(\mathrm{V}_{\mathrm{w}}\right)$ sesuai dengan variasi panjang pipa pemasukan dan simulasi menggunakan perangkat lunak Computational Fluid Dynamics (CFD).

\section{TINJAUAN PUSTAKA}

Untuk kebutuhan penelitian bahkan sampai dengan tingkat desain, perlu dibutuhkan suatu alat yang mampu menganalisis atau memprediksi dengan cepat dan akurat. Maka berkembanglah suatu ilmu yang dinamakan Computational Fluid Dynamic (CFD) yang dalam bahasa Indonesia dikenal dengan Komputasi Aliran Fluida Dinamik [1].

a. Proses Simulasi CFD

Pada umumnya terdapat tiga tahapan yang harus dilakukan ketika melakukan simulasi pada solver CFD, yaitu sebagai berikut [2] :

1. Preprocessing

2. Solving

3. Postprocessing

Beberapa prosedur yang digunakan pada semua pendekatan program CFD, yaitu sebagai berikut[3] :

- Pembuatan geometri dari model atau problem.

- Bidang atau volume yang diisi fluida dibagi menjadi sel-sel kecil (meshing).

- Pendefinisian model fisiknya, misalnya persamaan-persamaan gerak + entalpi + konversi species

- Pendefinisian kondisi-kondisi batas, termasuk di dalamnya sifat-sifat dan perilaku dari batas-batas model atau problem.

- Analisis dan visualisasi dari solusi CFD.

b. Persamaan Pembentuk Aliran

Pemodelan dengan metode komputasi pada dasarnya menggunakan persamaan dasar dinamika fluida, momentum, dan energi. Persamaan-persamaan ini merupakan pernyataan matematis untuk tiga prinsip dasar fisika [2] :

1. Hukum Kekekalan Massa (The Conservation of Mass)

2. Hukum Kekekalan Momentum (The Conservation of Momentum) sebagai interpretasi dari hukum kedua Newton (Newton Second's Law of Motion)

3. Hukum Kekekalan Energi (The Conservation Of Energi)

1. Hukum Kekekalan Massa (The Conservation of Mass)

Secara umum hukum kekekalan massa (The Conservation of Mass) 3 dimensi dapat ditulis dengan persamaan sebagai berikut.

$\frac{\partial \rho}{\partial t}+u \frac{\partial \rho}{\partial x}+v \frac{\partial \rho}{\partial y}+w \frac{\partial \rho}{\partial z}+\rho\left(\frac{\partial u}{\partial x}+\frac{\partial v}{\partial y}+\frac{\partial w}{\partial z}\right)=0$ 


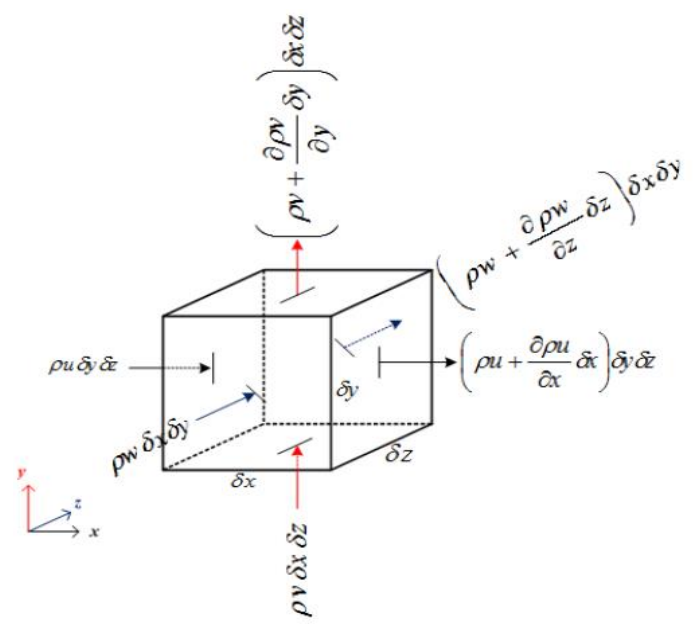

Gambar 1.Hukum Kekekalan Massa pada Sebuah Elemen Fluida 3 Dimensi [4]

\section{Hukum Kekekalan Momentum (The Coservation of Momentum)}

Secara umum hukum kekekalan momentum (The Conservation of Momentum) arah sumbu-x 3 dimensi dapat ditulis dengan persamaan sebagai berikut.

$\rho \frac{D u}{D t}=-\frac{\partial \rho}{\partial t}+\frac{\partial \sigma_{x x}}{\partial x}+\frac{\partial \tau_{y x}}{\partial y}+\frac{\partial \tau_{z x}}{\partial z}+\rho f_{x}$

$\rho \frac{D v}{D t}=-\frac{\partial \rho}{\partial t}+\frac{\partial \sigma_{x y}}{\partial x}+\frac{\partial \tau_{y y}}{\partial y}+\frac{\partial \tau_{z}}{\partial z}+\rho f_{y}$

$\rho \frac{D w}{D t}=-\frac{\partial \rho}{\partial t}+\frac{\partial \sigma_{x z}}{\partial x}+\frac{\partial \tau_{y z}}{\partial y}+\frac{\partial \tau_{z z}}{\partial z}+\rho f_{z}$

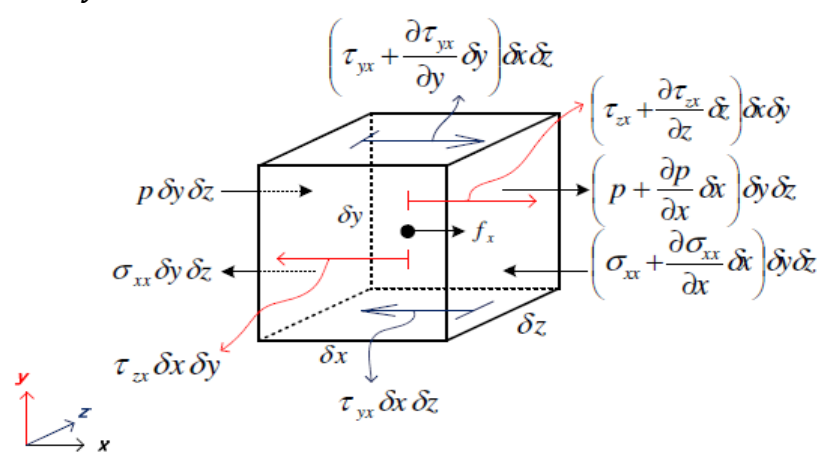

Gambar 2. Hukum Kekekalan Momentum Arah Sumbu-x pada Sebuah Elemen Fluida 3 Dimensi [4]

\section{Hukum Kekekalan Energi (The Conservation of Energy)}

Hukum ini merupakan aplikasi dari hukum ketiga fisika (termodinamika) yaitu laju perubahan energi dalam suatu elemen adalah sama dengan jumlah net fluks panas yang masuk ke dalam elemen dan kerja yang digunakan dalam elemen tersebut.

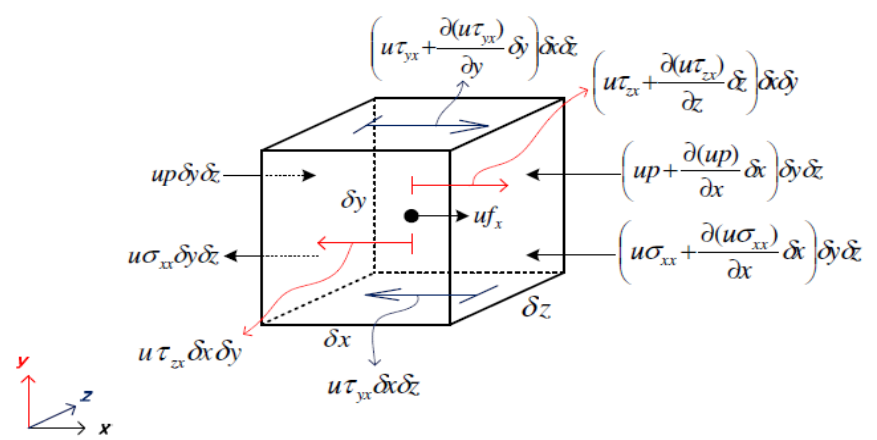

Gambar 3. Kerja yang Dikenakan pada Sebuah Elemen Arah Sumbu-x [4] 


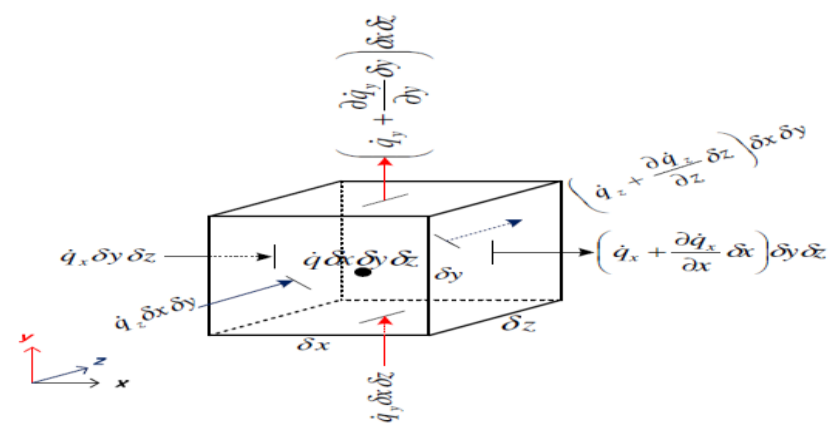

Gambar 4. Fluks Panas yang Melintasi Permukaan Sebuah Elemen [4]

Secara umum kerja yang dikenakan arah sumbu-x, sumbu-y, dan sumbu-z dapat ditulis dengan persamaan berikut.

$$
\begin{aligned}
\dot{\mathbf{W}}_{\mathbf{x}}=\left[-\frac{\partial(\mathbf{u p})}{\partial \mathbf{x}}+\frac{\partial\left(\mathbf{u} \sigma_{\mathbf{x x}}\right)}{\partial \mathbf{x}}+\frac{\partial\left(\mathbf{u} \tau_{\mathbf{y x}}\right)}{\partial \mathbf{y}}+\frac{\partial\left(\mathbf{u} \tau_{\mathbf{z x}}\right)}{\partial \mathbf{z}}+\mathbf{u p f}_{\mathbf{x}}\right] \delta \mathbf{V} \\
\dot{\mathbf{W}}_{\mathbf{y}}=\left[-\frac{\partial(\mathbf{v p})}{\partial \mathbf{y}}+\frac{\partial\left(\mathbf{v} \tau_{\mathbf{x y}}\right)}{\partial \mathbf{x}}+\frac{\partial\left(\mathbf{v} \sigma_{\mathbf{y y}}\right)}{\partial \mathbf{y}}+\frac{\partial\left(\mathbf{u} \tau_{\mathbf{z y}}\right)}{\partial \mathbf{z}}+\mathbf{u p f}_{\mathbf{y}}\right] \delta \mathbf{V} \\
\dot{\mathbf{W}}_{\mathbf{z}}=\left[-\frac{\partial(\mathbf{w p})}{\partial \mathbf{z}}+\frac{\partial\left(\mathbf{w} \tau_{\mathbf{x z}}\right)}{\partial \mathbf{x}}+\frac{\partial\left(\mathbf{w} \tau_{\mathbf{y z}}\right)}{\partial \mathbf{y}}+\frac{\partial\left(\mathbf{w} \sigma_{\mathbf{z z}}\right)}{\partial \mathbf{z}}+\mathbf{u p f}_{\mathbf{z}}\right] \delta \mathbf{V}
\end{aligned}
$$

\section{METODE PENELITIAN}

a. Pembuatan Model

Pembuatan model pompa hidram dalam simulasi ini mengacu kepada bentuk dan dimensi pompa yang sebenarnya. Pembuatan model CAD dilakukan dengan menggunakan perangkat lunak SolidWorks. Gambar 6 menunjukkan model pompa yang digambar menggunakan solidworks.
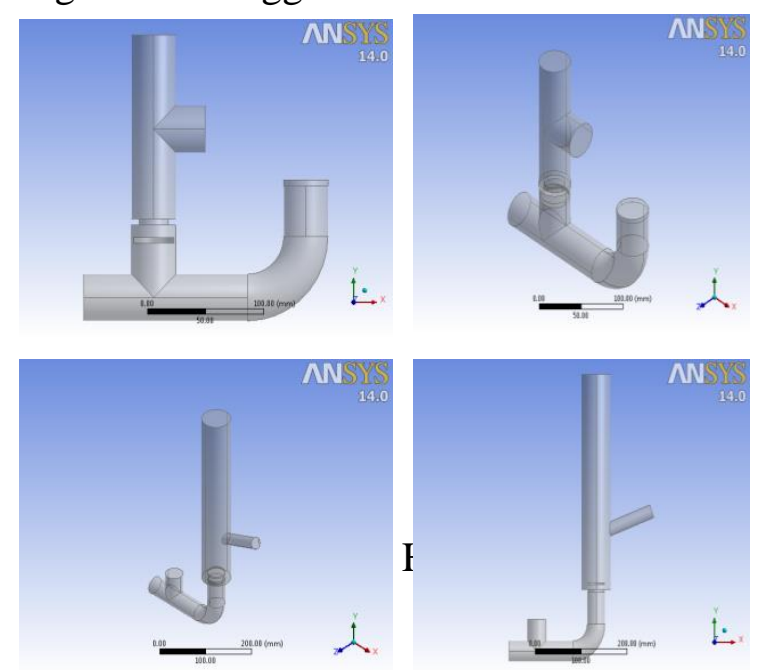

Gambar 6. Model Hidram

\section{b. Meshing}

Unit-unit volume pada simulasi ANSYS diinterpretasikan dengan pembentukan mesh atau grid. Ukuran mesh yang diterapkan pada model akan mempengaruhi ketelitian analisis CFD. Oleh karena itu, besar ukuran mesh harus diatur sedemikian rupa (smooth meshing) sehingga diperoleh hasil yang teliti dan diusahakan daya komputasi yang dibutuhkan tidak terlalu besar.

Dari gambar 7 dapat dilihat model pompa hidram yang telah di mesh. 


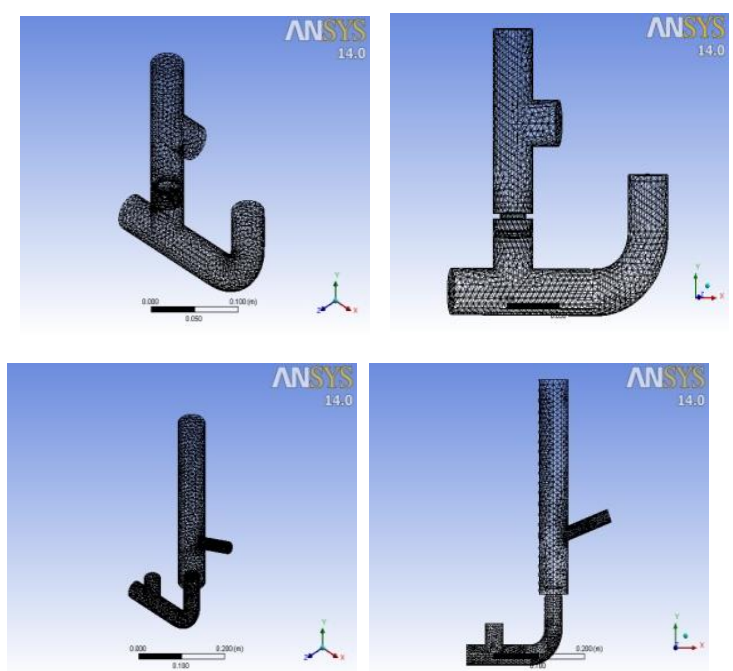

Gambar 7. Model hidram yang telah di mesh

c. Solution Solver

1. Jenis aliran berikut:

Fluida yang digunakan dalam simulasi adalah air dengan sifat-sifat sebagai

- Temperatur konstan $\mathrm{T}=20{ }^{0} \mathrm{C}$

- Kerapatan (densitas) konstan, $\rho=998.2 \mathrm{~kg} / \mathrm{m}^{3}$

- Viskositas kinematik, $u=1.02 \times 10^{-6} \mathrm{~m}^{2} / \mathrm{s}$

Dengan membandingkan nilai diatas dengan nilai kritis bilangan Reynold, maka jenis aliran adalah turbulen. Dari asumsi fluida yang digunakan adalah dengan temperature dan densitas tetap sehingga jenis alirannya adalah isothermal dan inkompresible.

\section{Boundary Condition}

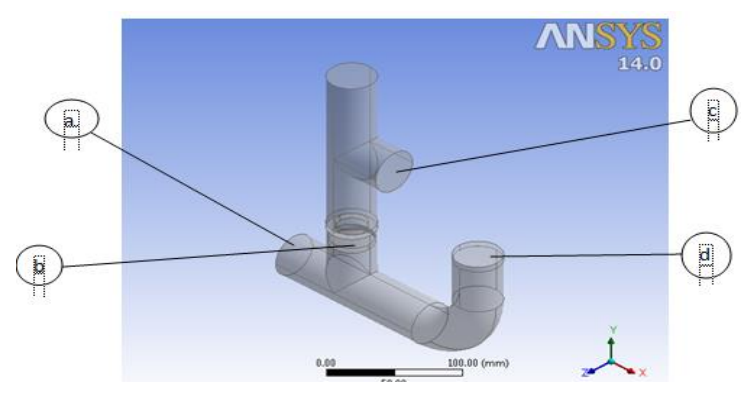

Gambar 8. Kondisi batas pada saat katup penghantar tertutup

Tabel 1. Kondisi batas pada saat katup penghantar tertutup

\begin{tabular}{|l|l|l|}
\hline \multicolumn{1}{|c|}{ Kondisi Batas } & \multicolumn{1}{|c|}{ Jenis } & \multicolumn{1}{|c|}{ Nilai } \\
\hline a. Inlet & Velocity inlet & $0.3925,0.3513,0.3424(\mathrm{~m} / \mathrm{s})$ \\
b. Katup limbah & Wall & - \\
c. Lobang limbah & Pressure outlet & $0 \mathrm{~Pa}$ (gauge) \\
d. Katup penghantar & Wall & - \\
\hline
\end{tabular}


Kondisi batas pada saat katup penghantar tertutup ditunjukkan pada gambar 8 dan tabel 1 diatas. Sedangkan kondisi batas pada saat katup penghantar terbuka ditunjukkan pada gambar 9 dan tabel 2 dibawah ini.

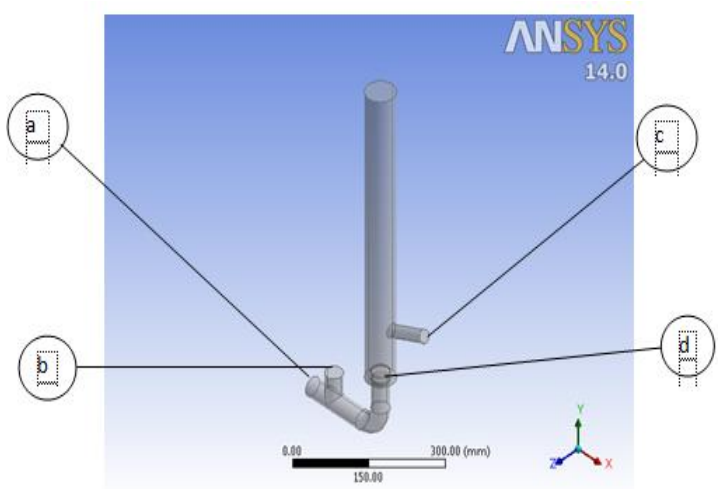

Gambar 9. Kondisi batas pada saat katup limbah tertutup

Tabel 2. Kondisi batas pada saat katup limbah tertutup

\begin{tabular}{|l|l|l|}
\hline \multicolumn{1}{|c|}{ Kondisi Batas } & \multicolumn{1}{|c|}{ Jenis } & \multicolumn{1}{|c|}{ Nilai } \\
\hline a. Inlet & Velocity inlet & $0.3925,0.3513,0,3424,0.3756$, \\
& & $0.3726,0.3599(\mathrm{~m} / \mathrm{s})$ \\
b. Katup Limbah & Wall & - \\
c. Outlet Delivery & Pressure Outlet & 0 Pa (gauge) \\
d. Katup Hantar & Wall & - \\
\hline
\end{tabular}

3. Pengaturan Simulasi

Pengaturan simulasi yang dimaksud adalah menentukan beberapa aspek yang diperlukan dalam simulasi seperti bentuk solver yang dipilih, material, jenis viskos, sesuai dengan asumsi yang dilakukan. Tabel 3 menunjukkan pengaturan simulasi yang dilakukan. Jenis aliran yang telah ditentukan sebelumnya juga diatur pada bagian ini di dalam Fluent.

Tabel 3. Pengaturan simulasi

\begin{tabular}{|l|l|}
\hline \multicolumn{1}{|c|}{ Aspek } & \multicolumn{1}{|c|}{ Pengaturan } \\
\hline Model Solver (Solver Model) & Pressure based, 3D, Steady \\
Model Viskos (Viscous Model) & Turbulent $\mathrm{k}-\mathrm{\varepsilon}$ Standard \\
Material & Water liquid with constant density, \\
& $\rho=998.2 \mathrm{~kg} / \mathrm{m}^{3}$ \\
KondisiOperasi (Operating Condition) & $101325 \mathrm{~Pa}$ \\
Inisiasi (Initialize) & Velocity Inlet \\
Residual Monitor & $10^{-4}$ \\
Time Step Size & $60 \mathrm{~s}$ \\
\hline
\end{tabular}




\section{HASIL DAN ANALISA}

Simulasi ini terdiri atas dua kondisi yaitu pada saat katup penghantar tertutup, dan pada saat katup limbah tertutup.

a. Simulasi Pada Saat Katup Penghantar Tertutup.

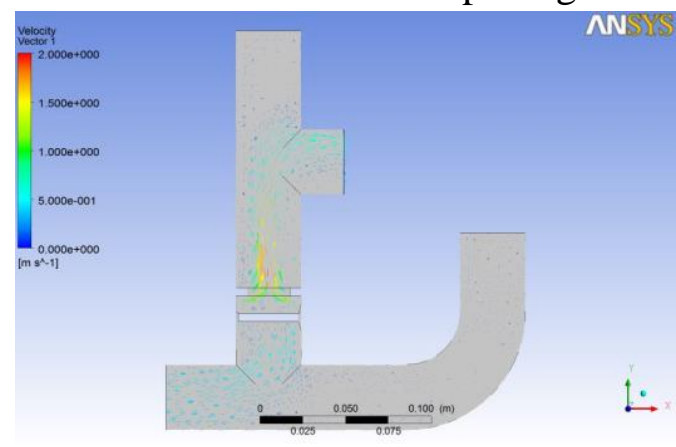

(a)

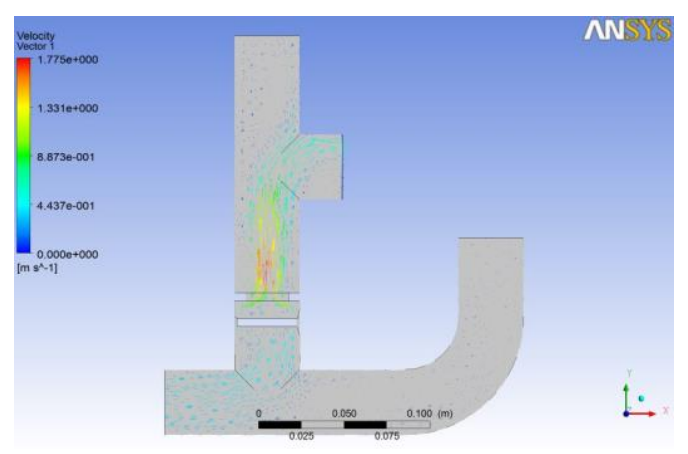

(b)

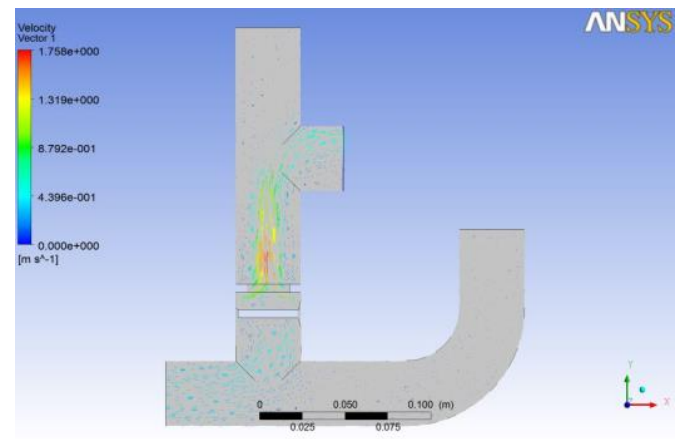

(c)

Gambar 10. Vektor kecepatan dengan panjang pipa pemasukan (a) 8m, (b) 10m, (c) $12 \mathrm{~m}$.

Dari gambar 10 dapat dilihat kecepatan pada tiap panjang pipa pemasukan berbeda, yaitu kecepatan pada katup limbah semakin menurun seiring dengan bertambah panjangnya panjang pipa pemasukan yaitu $0,3790 \mathrm{~m} / \mathrm{s}, 0,3385 \mathrm{~m} / \mathrm{s}$ dan $0,3377 \mathrm{~m} / \mathrm{s}$.

a. Simulasi Pada Saat Katup Limbah Tertutup

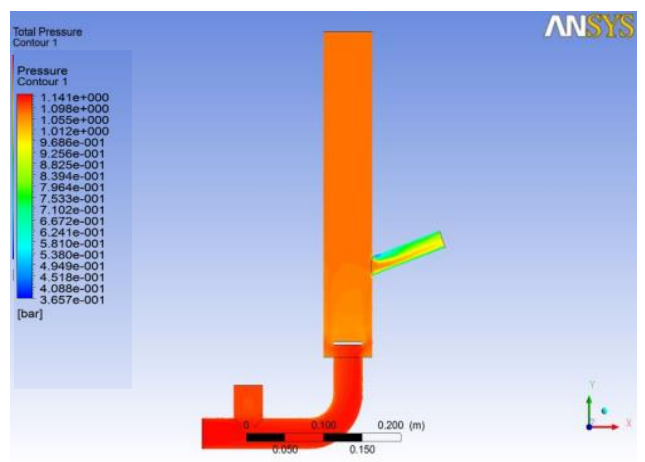

(a) 

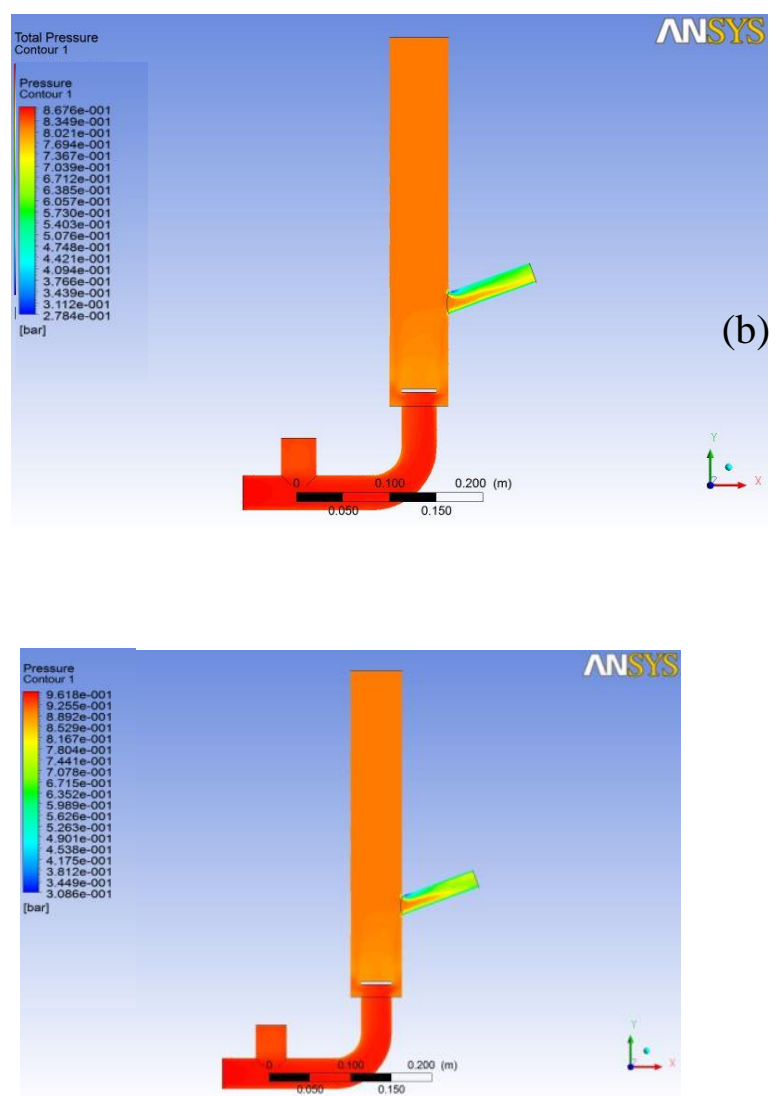

(c)

Gambar 11. Kontur tekanan dengan volume tabung 40 cm dengan panjang pipa pemasukan (a) $8 \mathrm{~m}$; (b) $10 \mathrm{~m}$; dan (c) $12 \mathrm{~m}$.
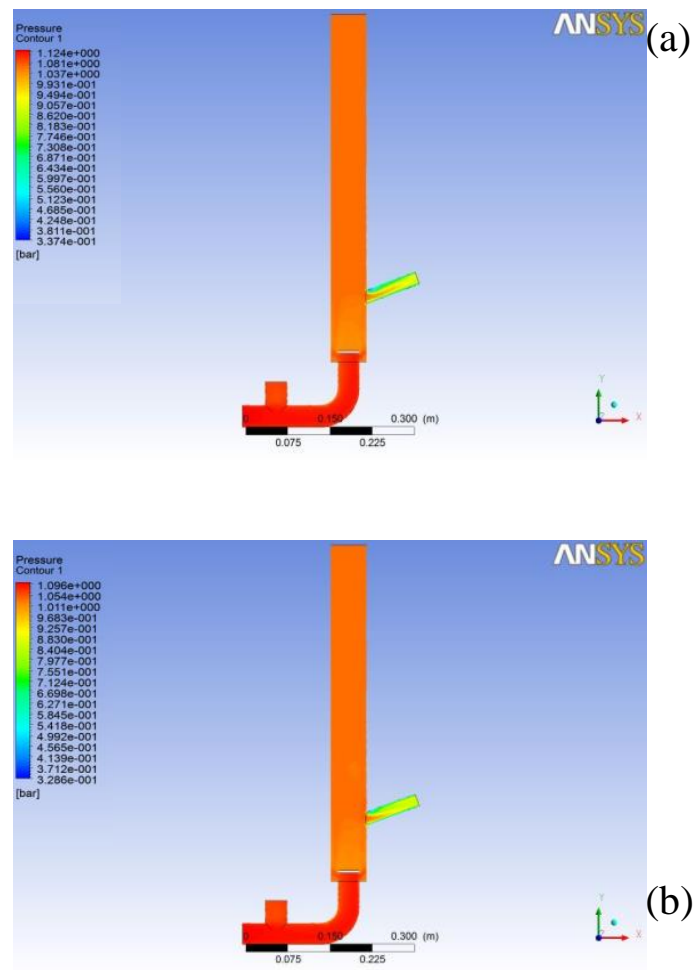


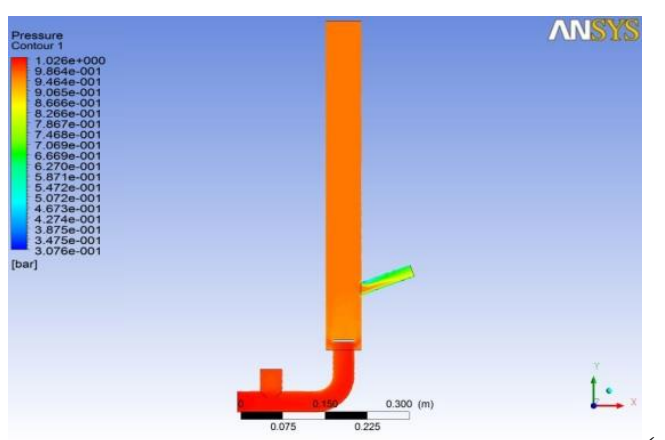

(c)

Gambar 12. Kontur tekanan dengan volume tabung $60 \mathrm{~cm}$ dengan panjang pipa pemasukan (a) $8 \mathrm{~m}$; (b) $10 \mathrm{~m}$; dan (c) $12 \mathrm{~m}$.

Pada kontur tekanan gambar 11 dan gambar 12 diatas dapat dilihat bahwa warna dari badan pompa dan tabung seperti sama karena tekanannya berada pada satu nilai warna skala, tetapi sebenarnya berbeda tiap bagian pompa. Tekanan pada tabung dan badan pompa berbeda sedikit, hal ini disebabkan karena peningkatan tekanan yang terjadi akibat adanya palu air.

Dan berikut adalah diagram batang perbedaan antara hasil simulasi dan hasil pengujian:

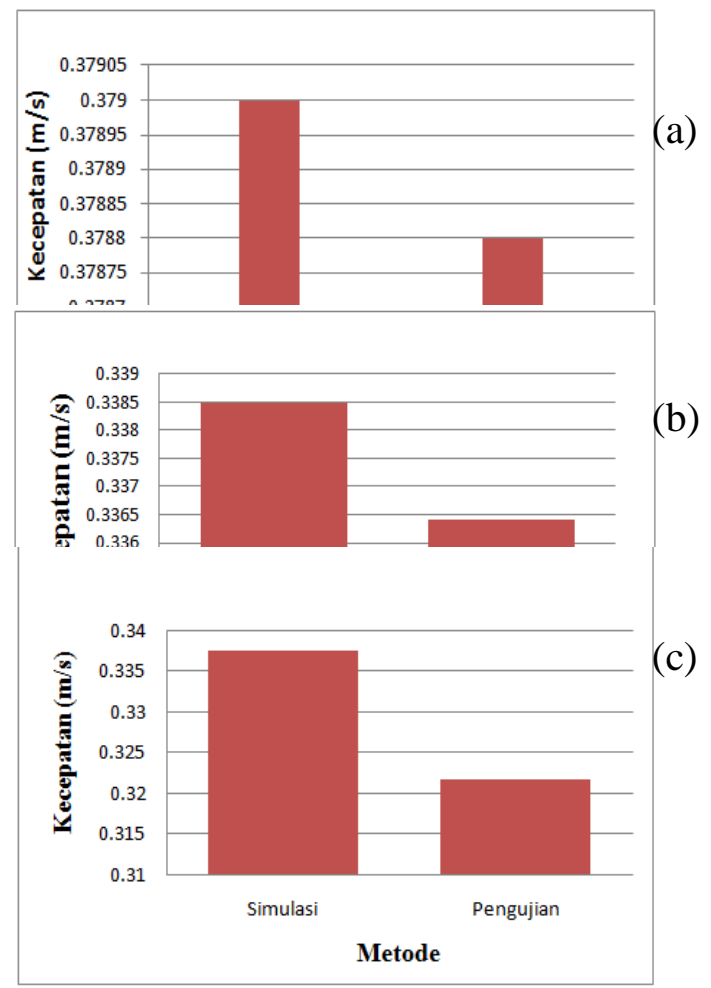

Gambar 13. Perbandingan hasil simulasi dan pengujian kecepatan pada panjang pipa pemasukan (a) $8 \mathrm{~m}$; (b) $10 \mathrm{~m}$; (c) $12 \mathrm{~m}$.

Dari gambar 13 dapat dilihat hasil simulasi lebih besar dari pengujian dengan nilai penyimpangan tidak lebih dari lima persen. 


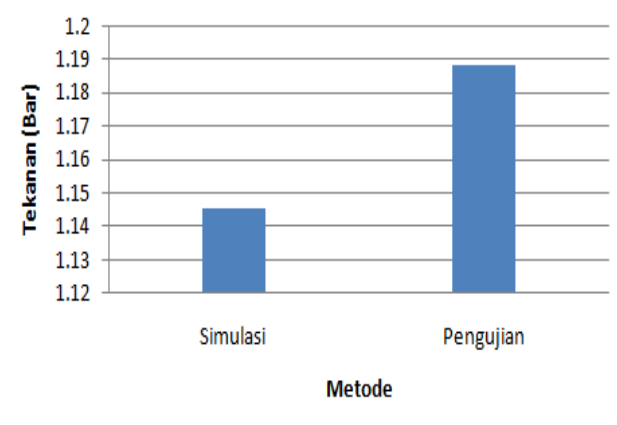

(a)

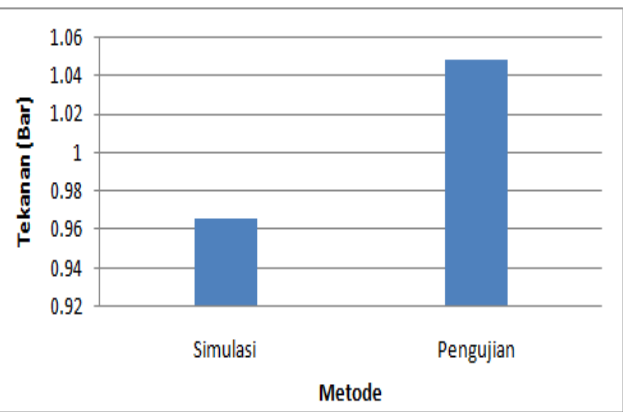

(b)

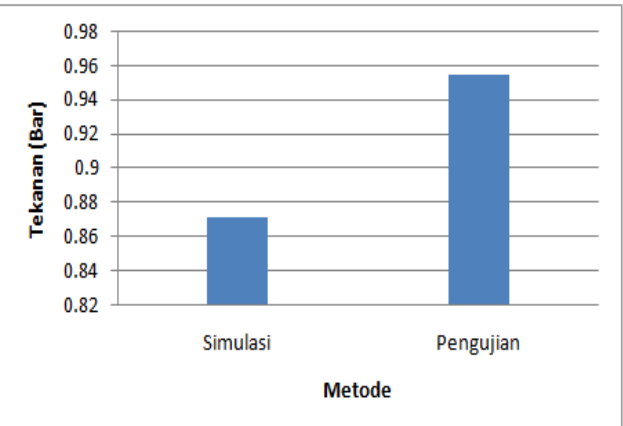

(c)

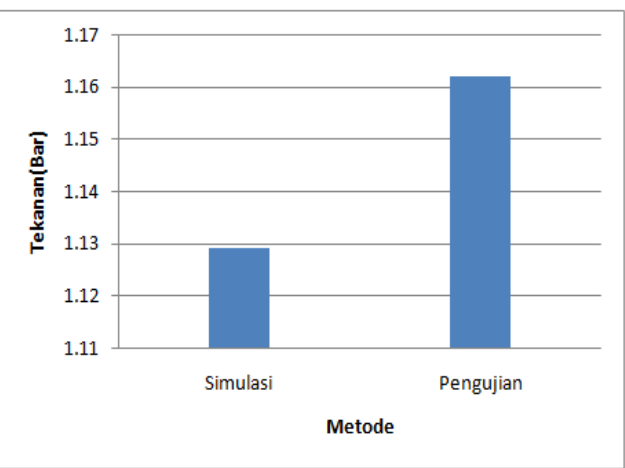

(d)

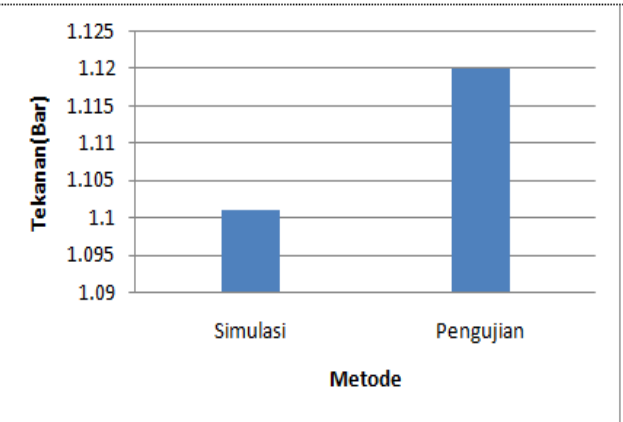

(e) 


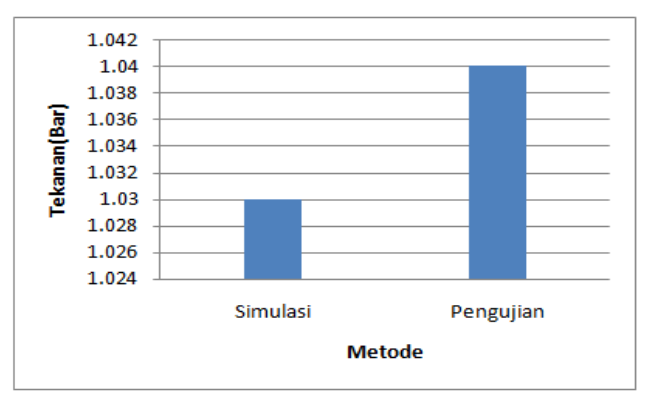

Gambar 14. Perbandingan hasil simulasi dan pengujian tekanan tabung pada (a) tabung $40 \mathrm{~cm}$, panjang pipa $8 \mathrm{~m}$; (b) $10 \mathrm{~m}$; (c) $12 \mathrm{~m}$; (d) tabung $60 \mathrm{~cm}$, panjang pipa $8 \mathrm{~m}$; (e) $10 \mathrm{~m}$; (f) $12 \mathrm{~m}$.

Dari gambar 14 dapat dilihat hasil simulasi lebih besar dari pengujian dengan nilai peyimpangan terbesar $9,50 \%$ yaitu pada tabung $40 \mathrm{~cm}$, panjang pipa $12 \mathrm{~m}$.

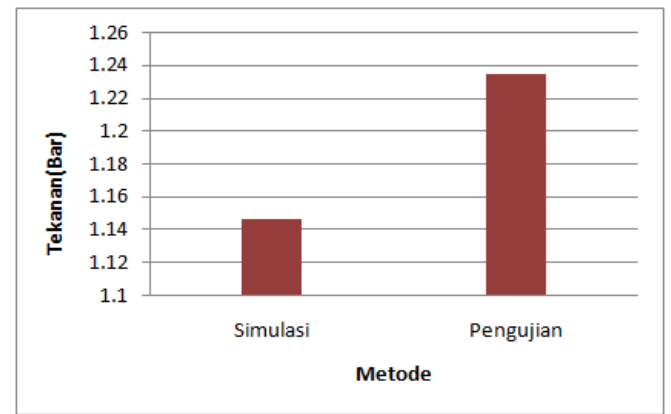

(a)

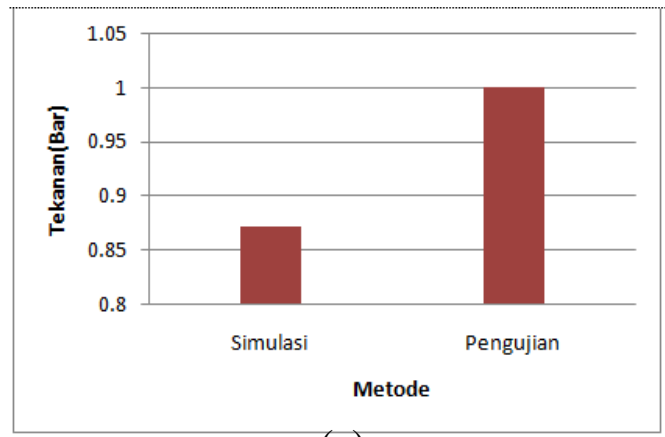

(c)

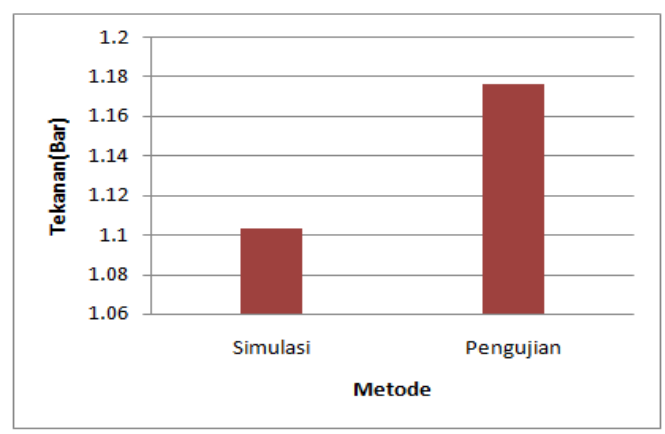

(e)

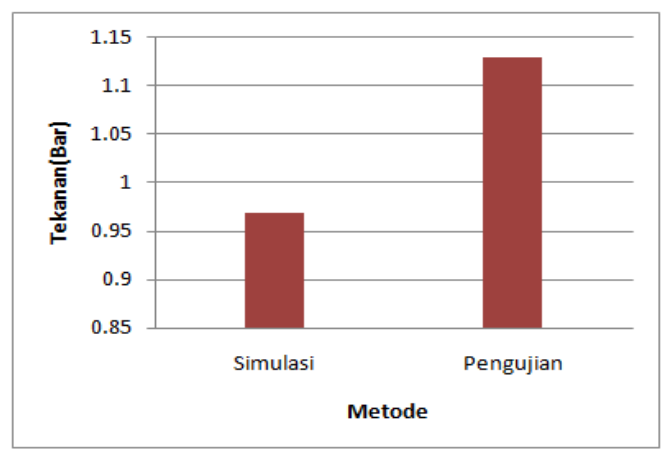

(b)

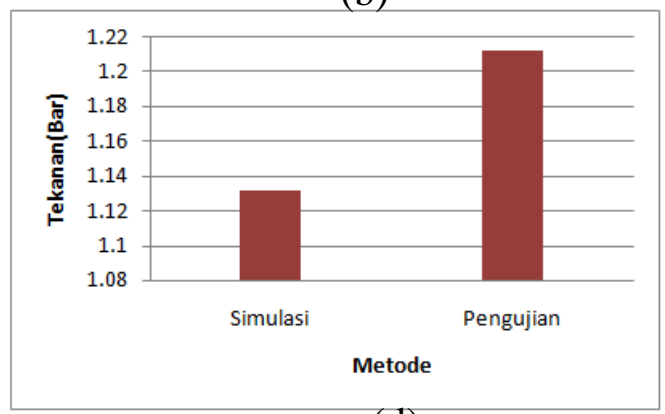

(d)

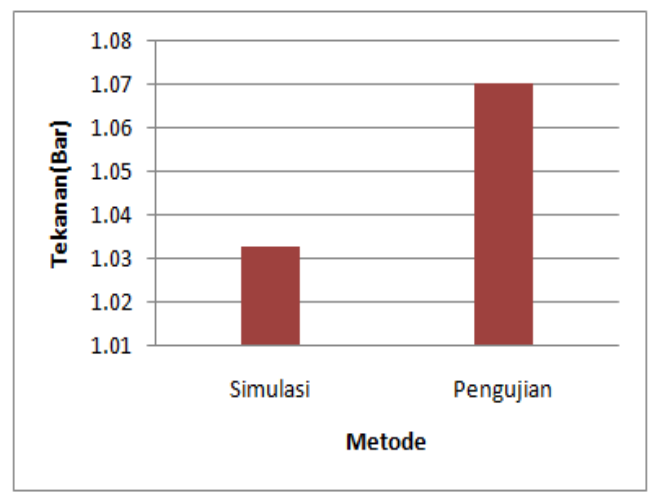

(f) 
Gambar 15. Perbandingan hasil simulasi dan pengujian tekanan badan pompa pada (a) tabung $40 \mathrm{~cm}$, panjang pipa $8 \mathrm{~m}$; (b) $10 \mathrm{~m}$; (c) $12 \mathrm{~m}$; (d) tabung $60 \mathrm{~cm}$, panjang pipa $8 \mathrm{~m}$; (e) $10 \mathrm{~m}$; (f) $12 \mathrm{~m}$.

Dari gambar 15 dapat kita lihat hasil simulasi lebih besar dari pengujian dengan nilai peyimpangan terbesar $16,58 \%$ yaitu pada tabung $40 \mathrm{~cm}$, panjang pipa $10 \mathrm{~m}$.

Menghitung besar penyimpangan antara hasil simulasi dan analisa:

Simpangan $=\left|\frac{\text { Simulasi-Pengujian }}{\text { Simulasi }}\right| \times 100 \%$

Dan berikut adalah besar penyimpangannya.

Tabel 4. hasil simulasi dan hasil pengujian dan penyimpangannya.

\begin{tabular}{|l|c|c|r|}
\hline Variabel & Simulasi & Pengujian & Penyimpangan \\
\hline $\mathrm{v}(8 \mathrm{~m})$ & $0,3790 \mathrm{~m} / \mathrm{s}$ & $0,3788 \mathrm{~m} / \mathrm{s}$ & $0,05 \%$ \\
\hline $\mathrm{v}(10 \mathrm{~m})$ & $0,3385 \mathrm{~m} / \mathrm{s}$ & $0,3364 \mathrm{~m} / \mathrm{s}$ & $1,90 \%$ \\
\hline $\mathrm{v}(12 \mathrm{~m})$ & $0,3377 \mathrm{~m} / \mathrm{s}$ & $0,3217 \mathrm{~m} / \mathrm{s}$ & $4,73 \%$ \\
\hline $\mathrm{v}(10 \mathrm{~m}-\mathrm{mm})$ & $11,5616 \mathrm{c} \mathrm{m}$ & $1,100 \mathrm{D}$ & 2,700 \\
\hline $\mathrm{P}_{1}(60 \mathrm{~cm} ; 8 \mathrm{~m})$ & $1,129391 \mathrm{Bar}$ & $1,162 \mathrm{Bar}$ & $2,89 \%$ \\
\hline $\mathrm{P}_{2}(60 \mathrm{~cm} ; 8 \mathrm{~m})$ & $1,131207 \mathrm{Bar}$ & $1,212 \mathrm{Bar}$ & $7,14 \%$ \\
\hline $\mathrm{P}_{1}(60 \mathrm{~cm} ; 10 \mathrm{~m})$ & $1,101221 \mathrm{Bar}$ & $1,120 \mathrm{Bar}$ & $1,72 \%$ \\
\hline $\mathrm{P}_{2}(60 \mathrm{~cm} ; 10 \mathrm{~m})$ & $1,103035 \mathrm{Bar}$ & $1,176 \mathrm{Bar}$ & $6,61 \%$ \\
\hline $\mathrm{P}_{1}(60 \mathrm{~cm} ; 12 \mathrm{~m})$ & $1,030951 \mathrm{Bar}$ & $1,040 \mathrm{Bar}$ & $0,97 \%$ \\
\hline $\mathrm{P}_{2}(60 \mathrm{~cm} ; 12 \mathrm{~m})$ & $1,032606 \mathrm{Bar}$ & $1,070 \mathrm{Bar}$ & $3,68 \%$ \\
\hline
\end{tabular}

Dari tabel 4 dapat dilihat penyimpangan tertinggi ada pada tekanan badan pompa dengan tinggi tabung $40 \mathrm{~cm}$ dan pada panjang pipa pemasukan $10 \mathrm{~m}$ yaitu $16,58 \%$, sedangkan penyimpangan terendah ada pada kecepatan (v) katup limbah dengan panjang pipa pemasukan $8 \mathrm{~m}$ yaitu $0,05 \%$.

\section{KESIMPULAN}

Dari hasil simulasi yang dilakukan maka dapat disimpulkan sebagai berikut :

1. Telah dilakukan simulasi dengan menampilkan distribusi kecepatan dan distribusi tekanan pada pompa hidram dengan kondisi masing-masing proses kerja Hidram.

2. Dari hasil simulasi kecepatan (v) katup limbah untuk tiap panjang pipa pemasukan adalah $0,3790,0,3385$ dan $0,3377 \mathrm{~m} / \mathrm{s}$ sedangkan hasil pengujian adalah 0,$3788 ; 0,3364$ dan $0,3217 \mathrm{~m} / \mathrm{s}$. Demikian juga dengan tekanan tabung $\left(\mathrm{P}_{1}\right)$ dan tekanan badan pompa $\left(\mathrm{P}_{2}\right)$, tekanan menurun seiring semakin panjangnya pipa pemasukan dan semakin tingginya tabung. Hasil simulasi tekanan $\left(\mathrm{P}_{1}\right)$ dengan tinggi tabung $40 \mathrm{~cm}$ dan panjang pipa $8 \mathrm{~m}, 10 \mathrm{~m}, 12 \mathrm{~m}$ adalah 1,145616 Bar, 0,965807 Bar, 0,871204 Bar. Hasil simulasi tekanan $\left(\mathrm{P}_{2}\right)$ dengan tinggi tabung $40 \mathrm{~cm}$ dan panjang pipa $8 \mathrm{~m}, 10 \mathrm{~m}, 12 \mathrm{~m}$ adalah 1,14775 Bar, 0,967541 Bar, 0,872775 Bar, hasil simulasi tekanan $\left(\mathrm{P}_{1}\right)$ dengan tinggi tabung $60 \mathrm{~cm}$ dan panjang pipa $8 \mathrm{~m}, 10 \mathrm{~m}, 12 \mathrm{~m}$ adalah 1,129931 Bar, 1,101221 Bar, 1,030951 Bar, hasil simulasi tekanan $\left(\mathrm{P}_{2}\right)$ dengan tinggi tabung $60 \mathrm{~cm}$ dan panjang pipa $8 \mathrm{~m}, 10 \mathrm{~m}, 12 \mathrm{~m}$ adalah 1,131207 Bar, 1,103035 Bar, 1,032606 Bar.

3. Diperoleh penyimpangan tertinggi ada pada tekanan badan pompa dengan tinggi tabung $40 \mathrm{~cm}$ dan pada panjang pipa pemasukan $10 \mathrm{~m}$ yaitu $16,58 \%$, sedangkan penyimpangan terendah ada pada kecepatan (v) katup limbah dengan panjang pipa pemasukan $8 \mathrm{~m}$ yaitu $0,05 \%$. 
4. Penggunaan Pompa Hidram dalam lingkungan masyarakat membutuhkan biaya operasional yang murah karena tidak tergantung pada tenaga listrik atau bahan bakar.

\section{DAFTAR PUSTAKA}

[1] Ansys Inc. Ansys Fluent Documentation. Ansys Inc

[2] Tuakia, Firman. 2008. Dasar-dasar CFD menggunakan FLUENT. Informatika : Bandung

[3] Çengel, Yunus. A. dan Robert H. Turner. 2004. Fundamental of Thermal Fluid Sciences, New York: Mc. Graw Hill

[4] Jahja Hanafie \& Hans de longh, 1979, Buku Petunjuk untuk pembuatan dan pemasangan TEKNOLOGI POMPA HIDRAULIK RAM, ITB, Bandung.

[5] Jofri B. Sinaga, 2009, Perancangan Alat Pengujian Pompa Tanpa Motor (Hydram Pump) Untuk Mendukung Pelaksanaan Praktikum Prestasi Mesin Di Jurusan teknik Mesin Universitas Lampung. UNILA : Lampung

[6] Made Suarda \& IKG Wirawan. 2008. Jurnal Ilmiah Teknik Mesin. Kajian Eksperimental Pengaruh Tabung Udara Pada Head Tekanan Pompa Hidram. UNUD: Bali

[7] Panjaitan, Daniel Ortega. 2013. Rancang Bangun Pompa Hidram Dan Pengujian Pengaruh Tingggi Tabung Udara Dan Panjang Pipa Pemasukan Terhadap Unjuk Kerja Pompa Hidram. USU: Medan

[8] Taye, T. 1998. Hydraulic Ram Pump, Journal of the ESME, Vol II, No. 1

[9] Versteeg, H. K. \& Malalasekera, W. 1995. An Introduction To Computational Fluid Dynamics. New York: Longman Group

[10] White M. Frank \& Wilarjo, Liek Ph.D. Mekanika Zalir. Erlangga : Jakarta 